\title{
ADJUDICATIVE RETROACTIVITY
}

\section{IN ADMINISTRATIVE LAW}

\section{INTRODUCTION}

Although decided forty-five years ago, SEC v Chenery Corp. (Cbenery II $)^{1}$ remains the Supreme Court's leading statement on the issue of retroactivity in administrative adjudication. According to Chenery II, administrative agencies may give meaning to statutory terms through adjudication, even if the rules applied in a particular adjudication have not been previously announced. The Court acknowledged that "announcing and applying a new standard of conduct" in an adjudicative proceeding would have a retroactive effect, but concluded that the agency's duty to be faithful to the "statutory design or to legal and equitable principles" may override concerns about retroactivity. ${ }^{2}$

The Court has since reaffirmed the Chenery II principle, ${ }^{3}$ but it has not revisited in detail the issue of adjudicative retroactivity in the administrative law setting. Lower courts have struggled to strike a balance between, on the one hand, application of the rule the adjudicator believes at the time of adjudication to be the correct

* Abner Greene is Assistant Professor of Law, The University of Chicago Law School. AurHoR's Note: I thank Albert Alschuler, Anne-Marie Burley, Richard Epstein, Stephen Gilles, Philip Greene, Elena Kagan, Lawrence Lessig, Michael McConnell, Bernard Meltzer, Geoffrey Miller, Richard Posner, and Cass Sunstein for helpful eomments. I am grateful for financial assistance fronı the Russell J. Parsons Faculty Research Fund and the Robert B. Roesing Faculty Fund.

1332 US 194 (1947). This was the second of two identically captioned cases. I discuss both cases below in Part IIIA.

${ }^{2}$ Id at 203.

${ }^{3}$ NLRB v Bell Aerospace Co., 416 US 267 (1974).

(91992 by The University of Chicago. All rights reserved. 0-226-09574-6/92/1991-0006\$02.00 
one, and, on the other hand, the harm caused by applying "a new standard of conduct" to antecedent behavior. Based on the authority of the old chestnut Chenery $I I$, though, lower courts often defer to agency decisions to proceed by adjudication rather than by rulemaking, even when the agency is announcing a new rule. ${ }^{4}$

A newer chestnut, Chevron, U.S.A., Inc. $v$ Natural Resources Defense Council, Inc. ${ }^{5}$ has added another principle of deference to the administrative law lexicon. According to Chevron's two-stage test, if a reviewing court cannot determine congressional intent on a particular issue of statutory construction (stage 1), then the court should defer to a reasonable agency interpretation (stage 2), rather than construct what the court believes would be a generally sound rule of law.

Although Chevron might be considered jurisprudentially consistent with Cbenery II in establishing a rule of deference to administrative agencies, it contains instead the seed of Chenery II's undoing. For one can read Chevron as establishing not merely a principle of deference, but also a method for distinguishing between when agencies are following the law laid down by Congress, and when they are, in essence, acting as legislators in their own right. Serving as a clearer, contemporary statement of the lawmaking function of administrative agencies, Chevron can help us clarify the connection between that function and the problems caused by an untempered rule of adjudicative retroactivity. Specifically, if agency adjudicators are acting as lawmakers rather than law discerners, then applying adjudicative rules retroactively conflicts with widely accepted principles that disfavor legislative retroactivity. ${ }^{6}$ Chenery II's broad deference to administrative adjudicative retroactivity does not fit with deference to agency lawmaking, which is not bound by antecedent congressional intent, and which might occur through adjudication as well as rulemaking.

In Part II, I discuss the connection between values of the rule

\footnotetext{
${ }^{4}$ See note 44.

${ }^{5} 467$ US 837 (1984).

${ }^{6}$ Although Cbevron involved informal rulemaking, its logic about the line between congressional and agency lawmaking is applicable to adjudications such as $C b e n e r y ~ I I$ as well. See INS v Cardoza-Fonseca, 480 US 421 (1987) (drawing no distinction between rulemaking and adjudication in applying Cbevron); NLRB v United Food \& Comml. Workers Union, Local 23, 484 US 112 (1987) (same); Ronald Levin, Identifying Questions of Law in Administrative Law, 74 Georgetown L J 1, 23 (1985).
} 
of law and the concurrent norms of legislative prospectivity and adjudicative retroactivity. In Part III, I argue that adjudicative retroactivity should hold only when the premise that adjudicators are merely applying antecedent rules also holds. Specifically, when an adjudicator can ascertain congressional intent at Chevron stage 1 , it is appropriate to apply the interpretation retroactively, because the materials to determine congressional intent are available to citizens as well as adjudicators. When sufficient indicia of congressional intent are not available to answer the statutory question, however, then it is inappropriate to apply the adjudicative rule retroactively, because the question has become one of policy for the agency to decide (Cheoron stage 2), and notice of the agency's policy choice is not available until the agency uses the adjudication to make that choice. In Part IV, I respond to various defenses of Cbenery $I I$, which acknowledge the possible damage to values of the rule of law done by applying rules retroactively in some adjudications, but which nonetheless contend that the modern administrative state requires such retroactivity. Finally, in Part V, I defend the view that adjudicators may sometimes apply rules prospectively only.

\section{Adjudicative Retroactivity and the Rule of Law}

\section{A. THE VALUES OF THE RULE OF LAW}

Three aspects of the rule of law that are sometimes mentioned separately-notice of legal rules, prospective operation of the rules, and the ability to obey the rules ${ }^{7}$ - are interconnected in an important way. They focus on citizens' ability to conform their conduct to given rules. Citizens may be sanctioned only for departing from rules that they knew or should have known and to which they could have conformed.

We can reach two conclusions from the centrality of notice to the rule of law. First, the requirement of notice helps limit officials' power; that power can be exercised only in accordance with previ-

\footnotetext{
${ }^{7}$ Professor Fuller listed eight aspects of a properly "legal" regime: rules; notice of the rules; prospectivity of the rules; understandability of the rules; rules that are consistent with each other; rules that are possible to obey; rules that are sufficiently stable that they can be coherently followed; and a congruence between the announced rules and the administration thereof. Lon Fuller, The Morality of Law 33-94 (rev ed 1969).
} 
ously established rules. ${ }^{8}$ Second, by defining the bounds of governmental power, notice of the laws also helps shape the contours of personal freedom. Knowledge of the laws permits us to foresee the legal consequences of our actions and thus to plan our lives with confidence. By relying on the precept that only extant laws can circumscribe behavior, we can establish a secure arena for free action outside those limits. ${ }^{9}$

The norm of legislative prospectivity follows from the notice principle of the rule of law. Legislation involves the creation of general rules. If such rules were to apply retroactively-that is, if the rules were to "give[ ] to preenactment conduct a different legal effect from that which it would have had without the passage of the statute" 10 -the rule of law values of limiting officials' power and of providing for a safe realm of personal freedom would be undermined.

Conversely, adjudicative retroactivity is generally justified on the ground that adjudicators deciding cases arising under antecedently given rules are applying those rules to particular cases; they are not, on the orthodox view, creating the rules they apply. Thus, because both the adjudicators and the parties are on notice of the antecedent rules-and those are the ones that govern-adjudicative rulings can properly apply to the antecedent conduct that gave rise to the litigation. "Judicial decisions have had retrospective operation for near a thousand years." 11 A similar norm exists in agency adjudication. ${ }^{12}$

In many cases, the adjudicative retroactivity norm is uncontroversial, because the adjudicator is straightforwardly applying preexisting law. But a problem arises in at least two settings. First,

\footnotetext{
${ }^{8}$ See SEC v Chenery Corp., 332 US 194, 209 (1947) (Jackson dissenting); Friedrich Hayek, The Constitution of Liberty 131 (1960) (quoting Richard Hooker, 1 The Laws of Ecclesiastical Polity 192 (1593)).

${ }^{9}$ See California v Lo-Vaca Gatbering Co., 379 US 366, 371 (1965) (Harlan dissenting); Hayek, Constitution of Liberty at 21, 133-34, 157 (cited in note 8); John Rawls, A Theory of Justice 235-36, 239-41 (1971); Note, Prospective Overruling and Retroactive Application in the Federal Courts, 71 Yale L J 907, 910 (1962).

${ }^{10}$ Charles Hochman, The Supreme Court and the Constitutionality of Rctroactive Legislation, 73 Harv L Rev 692, 692 (1960).

${ }^{11}$ Kubn v Fairmont Coal Co., 215 US 349, 372 (1910) (Holmes dissenting).

12 See SEC v Cbenery Corp., 332 US 194 (1947); see also Bowen v Georgetown Univ. Hosp., $109 \mathrm{~S} \mathrm{Ct} 468,478$ (1988) (in the adjudicatory setting, "retroactivity is not only permissible but standard") (Scalia concurring); NLRB v Bell Aeraspace Co., 416 US 267 (1974).
} 
when adjudicators overrule precedent, they strip the norm of adjudicative retroactivity of its legitimation based in the mere application of antecedent rules. The courts have acknowledged this problem, and have developed balancing tests that account for reliance on the old rule and the absence of notice that the new one would go into effect. ${ }^{13}$ Second, both the adjudicator and the citizen may have no good way of choosing between two or more possible readings of the relevant command. The typical case here is the interpretation of a vague statutory term that has not been previously fleshed out through either adjudication or rulemaking. To be sure, the adjudicative retroactivity norm applies more easily here than in the overruling context, for here at least the interpretive question is an open one. ${ }^{14}$ But if the question is too open, then binding citizens to one reading over another may be akin to asking them to obey a law of which they could not know.

One can envision an adjudicative spectrum from pure application of law-cases in which there is no reasonable disagreement about what the law means in a particular setting-to pure creation of law-instances in which all would agree that the rule the adjudica-

${ }^{13}$ If a party has conformed its conduct to a prior legal regime, adjudicators sometimes forbid retroactive application of a new legal rule. See Air Transport Aon. $v$ CAB, 732 F2d 219 (DC Cir 1984); Patel v INS, 638 F2d 1199 (9th Cir 1980); Natural Gas Pipeline Co. v FERC, 590 F2d 664 (7th Cir 1979); Drug Package, Inc. v NLRB, 570 F2d 1340 (8th Cir 1978). Conversely, the absence of conduct based on a prior legal regime will weigh in favor of retroactivity. Thus, if the citizen's response to a changing legal regime is considered inelastic, i.e., if the relevant behavior is not responsive to the legal rules, then new rules will be applied retroactively. See Ballbe v INS, 886 F2d 306 (11th Cir 1989), cert deried, $110 \mathrm{~S} \mathrm{Ct}$ 2166 (1990); Texaco, Inc. v Department of Energy, 795 F2d 1021 (Temp Emerg Ct App 1986), cert dismissed, 478 US 1030 (1986); NLRB v Affiliated Midwest Hosp., Inc., 789 F2d 524 (7th Cir 1986); NLRB v Ensign Elec. Div., 767 F2d 1100 (4th Cir 1985), cert denied, 479 US 984 (1986); NLRB v Niagara Mach. \& Tool Works, 746 F2d 143 (2d Cir 1984). Similarly, if a party is on notice of the strong likelihood of legal change, the argument against retroactivity might run aground. See NLRB v Wayne Transp., 776 F2d 745 (7th Cir 1985); NLRB v Ensign Elec. Div., 767 F2d 1100 (4th Cir 1985), cert denied, 479 US 984 (1986); Local 900 vLRB, 727 F2d 1184 (DC Cir 1984); California v Simon, 504 F2d 430 (Temp Emerg Ct App), cert denied, 419 US 1021 (1974).

${ }^{14}$ It is rare to find judicial invalidation of administrative adjudicative retroactivity in a fleshing-out case, which does not involve departure from administrative precedent. For an example, see J.L. Foti Constr. Co. $v$ OSHRC, 687 F2d 853 (6th Cir 1982). In the civil judicial setting, courts sometimes trcat the "new law" problem of fleshing-out cases with the same caution that they treat overruling cases, but without significant analysis. See Cbevron Oil Co. v Huson, 404 US 97, 106 (1971) (prospective application if rule announced either by overruling or "by deciding an issue of first impression whose resolution was not clcarly foreshadowed"); Halliday v United States, 394 US 831, 833 (1969) (Harlan concurring in the result); Desist v United States, 394 US 244, 269 (1969) (Fortas dissenting); Allen v State Bd. of Elections, 393 US 544, 572 (1969) (questions "involve complex issues of first impressionissues subject to rational disagreement"); Kubn v Fairmont Coal Co., 215 US 349 (1910). 
tor uses to resolve the case has no pedigree in extant sources of law. The legitimacy of adjudicative retroactivity varies directly with the position of a case on this spectrum from law's application to its creation, because the strength of adjudicative constraints, of the sources of law that bind adjudicative decisions, mirrors the strength of notice available to the affected citizens. In the easy cases in which the constraints are strong, the citizens as well as the adjudicators are on notice of how the law must apply in the relevant setting. But if the constraints are weak-the extreme case is the one in which the legislature tells the adjudicator, "make up the law as the cases come before you"-then notice of what the law means is weak as well.

\section{B. POSITIVE SOURCES OF LAW FOR RESTRICTING} ADJUDICATIVE RETROACTIVITY

Much that follows in this article depends upon applying the norm of legislative prospectivity to administrative adjudications that are properly deemed "legislative." Although my argument is based in the general values of the rule of law that undergird the legislative prospectivity norm, for the argument to have force in the American legal system, these values must find a constitutional or statutory anchor. The Constitution expressly addresses retroactive lawmaking in two ways, by prohibiting ex post facto laws ${ }^{15}$ and laws impairing the obligation of contracts. ${ }^{16}$ But the Supreme Court has held that the Ex Post Facto Clause applies only to criminal laws, ${ }^{17}$ and the Contracts Clause is limited in other ways that render it less than a general constitutional prohibition against retroactive lawmaking. ${ }^{18}$

The Due Process Clause ${ }^{19}$ could be read to support a general

${ }^{15}$ US Const, Art I, § 9, cl $3 \& \S 10, \mathrm{cl} 1$.

${ }^{16}$ US Const, Art I, $\$ 10$, cl 1.

${ }^{17}$ Calder v Bull, 3 Dallas 386 (1798).

${ }^{18}$ For one thing, the Contracts Clause (as well as the Ex Post Facto Clause) applies only to legislative and not to adjudicative action; see Central Land Co. v Laidley, 159 US 103 (1895); Thomas Currier, Time and Cbange in Judge-Made Law: Prospective Overruling, $51 \mathrm{Va}$ L Rev 201, 207 (1965) (citing cases); Edward Stimson, Retroactive Application of Law-A Problem in Constitutional Law, 38 Mich L Rev 30, 50 (1939); Note, 71 Yale L J at 909 (cited in note 9) (citing cases), so it would be an awkward textual basis for applying the norm of legislative prospectivity to "legislative" adjudications. Moreover, the Contracts Clause textually applies only to the impairment of "contracts," and not to other regulation.

${ }^{19}$ US Const, Amend V \& Amend 14, §1. 
constitutional requirement of prospective lawmaking; one of the core due process values is that citizens must be given notice before being deprived of life, liberty, or property. ${ }^{20}$ But the Court has been inconsistent in its application of the Due Process Clause to retroactive legislation. On the one hand, the Court requires Congress to state clearly if it intends to alter retroactively the legal status of antecedent conduct; moreover, the Court sometimes strains to read a law as applying merely prospectively. A venerable line of cases supports these propositions. ${ }^{21}$

On the other hand, when Congress has expressly legislated retroactively, the Court has found a variety of ways to uphold the legislation against due process challenge. In at least two settings, the holdings can be at least somewhat reconciled with the values of the rule of law. The Court's approval of laws that alter the tax consequences of prior conduct is based in part in the notion that the tax bar follows pending legislation and can inform its clients of possible legislative changes. ${ }^{22}$ In addition, if the Court concludes that the earlier conduct would not have been different had the later, retroactive law then governed, it will uphold the law. ${ }^{23}$ But the Court has also upheld expressly retroactive legislation after applying nothing more than a version of the rational basis test. In one case, it approved retroactive compensation for coal miners, essentially on the theory that Congress can choose to redistribute wealth retroactively as well as prospectively. ${ }^{24}$ In another case, it upheld a law imposing retroactive liability on employers withdraw-

\footnotetext{
${ }^{20}$ Such a due-process based doctrine could draw on the rule of lenity, fair warning, and vagueness cases, all of which constrain application of vague statutory terms based on the rule of law value of notice. See Bell v United States, 349 US 81, 83 (1955); Bouie v City of Columbia, 378 US 347, 350-51 (1964); Papacbristouv $v$ City of Jacksonville, 405 US 156, 166-67 (1972); Marks v United States, 430 US 188, 191-92 (1977).

${ }^{21}$ See United States $v$ Heth, 3 Cranch 399 (1806); Murray v Gibson, 15 Howard 421 (1854); White v United States, 191 US 545 (1903); Bowen v Georgetown Univ. Hosp., 109 S Ct 468 (1988); see also Kaiser Alum. \& Cbem. Corp. v Bonjorno, 110 S Ct 1570, 1579 (1990) (Scalia concurring).

${ }^{22}$ See United States $v$ Darusmont, 449 US 292 (1981); Welcb v Henry, 305 US 134 (1938). The Court has not extended this reasoning to other areas of law.

${ }^{23}$ See Bradley v Ricbmond Scbool Bd., 416 US 696 (1974) (later-enacted attorney's fees statute would not have changed school board's prior conduct); Welcb $v$ Henry, 305 US 134 (1938) (retroactive increase in income tax would not have altered citizen's prior conduct; distinguishes retroactive gift $\operatorname{tax}$ on theory that donor's decision whether to give gift might have been altered had tax previously existed).
}

${ }^{24}$ Usery v Turner Elkborn Mining Co., 428 US 1 (1976). 
ing from multiemployer pension plans, primarily on the ground that such liability was necessary to prevent flight. ${ }^{25}$ In short, although the Court applies a clear statement test in construing congressional statutes, the Due Process Clause stands as only a weak barrier when Congress expressly legislates retroactively. ${ }^{26}$

A final possible source of legal restriction on adjudicative retroactivity is the Administrative Procedure Act. The APA arguably forbids agencies to apply regulations retroactively, in large part because the APA states that a "rule," which is made in a rulemaking proceeding, is of "future effect." 27 There is a substantial argument to the contrary, ${ }^{28}$ however, and the Court has not resolved the matter.

My argument below could thus be supported in positive law in one of three ways. First: One could argue that Congress must clearly state when it intends to authorize agencies to make law

\footnotetext{
${ }^{25}$ Pension Benefit Guaranty Corp. v R.A. Gray \& Co., 467 US 717 (1984); see also General Motors Corp. $v$ Romein, 112 S Ct 1105, 1112 (1992) (upholding against due process challenge state legislation that reversed retroactively state supreme court interpretation that had, in turn, adopted unexpected retroactive interpretation of state legislation). In Gray, Congress was concerned that employers would flee plans once they learned a bill was under serious consideration, so the initial proposed bill clearly stated that withdrawal liability would begin on the day that bill was introduced. Once Congress was confident that employers were generally heeding the liability date, it advanced that date in the final law to a period five months prior to the law's enactment. Although the Court brushed aside the due process challenge, whether Congress should be permitted to gnide business behavior through signaling in a bill that liability will run from the bill's introduction date rather than the date of the law's enactment raises some perplexing separation of powers questions. See Metropolitan Wasbington Airports Autb. v Citizens for the Abatement of Aircraft Noise, Inc., 111 S Ct 2298 (1991) (Congress may not directly control policymaking other than by a law passed through the Article I, section 7 constitutional process); Bowsher v Synar, 478 US 714, 736 (1986) (Stevens concurring in the judgment) (same); INS v Cbadba, 462 US 919 (1983) (same).

${ }^{26}$ Similarly, although courts have sometimes refused to allow the applieation of adjudicatively created law of which a citizen could not have known, see SEC $v$ Cbenery Corp., 318 US 80 (1943) (Cbenery I, discussed in Part IIIA); Gelpcke $v$ City of Dubuque, 1 Wallace 175 (1864), the Court has at other times indicated, often implicitly, that applying a new rnle retroactively does not violate the Due Process Clause. See Vandenbark v Owens-Illinois Glass Co., 311 US 538 (1941); Great Nortbern R. Co. v Sunburst Oil or Refining Co., 287 US 358 (1932).

275 USC § 551(4); see Bowen v Georgetown Univ. Hosp., 109 S Ct 468, 475 (1988) (Scalia concurring).

${ }^{28}$ See Citizens to Save Spencer County v United States EPA, 600 F2d 844 (DC Cir 1979); William Luneberg, Retroactivity and Administrative Rulemaking, 1991 Duke L J 106, 134; Glen Robinson, Tbe Making of Administrative Policy: Anotber Look at Rulemaking and Adjudication and Administrative Procedure Reform, 4 U Pa L Rev 485, 498 (1970); Frederick Schauer, A Brief Note on the Logic of Rules, witb Special Reference to Bowen $v$ Georgetown University Hospital, 42 Admin L Rev 447 (1990); David Shapiro, The Cboice of Rulemaking or Adjudication in tbe Development of Administrative Policy, 78 Harv L Rev 921, 933 (1965).
} 
retroactively, either through rulemaking or through adjudication. This clear statement requirement, already present for reviewing legislation, is needed even more when examining the action of the unelected agencies. ${ }^{29}$ Second, one could maintain that the Court's weak review of expressly retroactive laws should be strengthened to accommodate the important values of the rule of law underlying the norm of legislative prospectivity, that the Due Process Clause is an appropriate constitutional source on which to base such heightened review, and that agency adjudication that is truly "legislative" should be reviewed in similarly strict fashion. Third, the APA could be read to require that agency adjudication correctly considered "legislative" must not be applied retroactively.

\section{What Administrative Adjudicators Do: From Chenery II to Chevron}

\section{A. THE CURRENT LAW OF ADMINISTRATIVE ADJUDICATIVE RETROACTIVITY: THE CHENERY II PRINCIPLE}

The Chenery II principle resulted from the second of two connected Supreme Court cases, both titled SEC $v$ Chenery Corp. ${ }^{30}$ The cases arose in the following fashion: During the reorganization of the Federal Water Service Corporation (Federal), corporate inanagement purchased preferred over-the-counter stock, which it then sought to convert into common stock under the reorganization plan. The SEC demied the conversion, requiring instead the surrender of the preferred stock at cost plus accumulated dividends. ${ }^{31}$ The SEC acted pursuant to the Public Utility Holding Company Act of 1935, which required it to determine whether the "terms of issuance of the new common stock were 'fair and equitable' or 'detrimental to the interests of investors."'32 Although the trades were made at market price and with complete disclosure of the purchasers' identity, the SEC relied on its understanding that common law fiduciary theory barred trustees from trafficking in property held for others. ${ }^{33}$

\footnotetext{
${ }^{29}$ See Hampton v Mow Sun Wong, 426 US 88 (1976); Kent v Dulles, 357 US 116 (1958).

${ }^{30} 318$ US 80 (1943) (Cbenery I); 332 US 194 (1947) (Cbenery II).

${ }^{31}$ See 318 US at 81-84; 332 US at 197-98.

32318 US at 85.

${ }^{33}$ Id at $85-90$.
} 
But as the Court explained in Chenery I, management does not hold the stock it owns in trust for the shareholders; furthermore, the SEC misread common law, which did not then impose restrictions against trading by corporate management during reorganization. Although the Act gives the SEC broad power to regulate securities practices, and to do so through adjudication as well as rulemaking, the Court concluded that the SEC must do so through standards of conduct existing and known to exist at the time of the purported infraction. As the Court explained: ${ }^{34}$

Had the Commission, acting upon its experience and peculiar competence, promulgated a general rule of which its order here was a particular application, the problem for our consideration would be very different. . . . But before transactions otherwise legal can be outlawed or denied their usual business consequences, they must fall under the ban of some standards of conduct prescribed by an agency of government authorized to prescribe such standards-either the courts or Congress or an agency to which Congress has delegated its authority. Congress itself did not proscribe the respondents' purchases of preferred stock in Federal. Established judicial doctrines do not condemn these transactions. Nor has the Commission, acting under the rulemaking powers delegated to it by sec. 11(e), promulgated new general standards of conduct.

Thus, not only had the SEC relied upon an erroneous understanding of the common law of corporate management fiduciary duty, but furthermore, and of importance for the retroactivity problem, the SEC had failed to identify another source of law-agency precedent or regulation, or an appropriate understanding of congressional intent in passing the governing statute-that prohibited the trades that Federal's management had made.

Although the above passage suggests that the Chenery I Court intended to require adjudication by standards extant at the time of the antecedent conduct, there is other language in the opinion indicating that the Court might have permitted the SEC to propose a new standard in the case before it and apply that standard retroactively. Thus, the opinion earlier states, "the Commission did not in this case proffer new standards reflecting the experience gained

${ }^{34}$ Id at 92-93. 
by it in effectuating the legislative policy." 35 The Court also noted, "The Commission did not rely upon its special administrative con1petence'; it formulated no judgment upon the requirements of the 'public interest or the interest of investors or consumers' in the situation before it." 36 These passages suggest that the Court would have permitted the SEC to flesh out a standard under its statutory authority in the Cbenery adjudication itself and to apply that standard to conduct predating its announcement. On this reading of Chenery $I$, the Court's primary concern was not the retroactivity problen, but the SEC's failure to announce or apply any standard whatsoever. ${ }^{37}$

But I need not show that Chenery $I$ got the retroactivity issue right while Chenery $I I$ did not. Chenery $I$ identified a problem with applying new rules to antecedent conduct. Chenery II represents at the very least a reversal in tone and attitude on this issue. As I shall explain below, values of the rule of law require resolving the adjudicative retroactivity problen in a way at odds with the Chenery II approach.

It is to Chenery II that I now turn. By renianding to the SEC rather than reversing outright, the Chenery $I$ Court left the door open for the SEC's next nove: Avoiding reliance on coninion law fiduciary theory, the Commission concluded that management's trades were inconsistent with the "purposes and standards" of the federal statute. ${ }^{38}$ Without concluding that the SEC's interpretation was coinmanded by an appropriate understanding of congressional intent, the Court in Chenery II gave great deference to the SEC's statutory construction and sustained its order. ${ }^{39}$ Regarding the retroactivity question-could the agency announce an interpretation of the statute neither previously announced nor commanded by congressional imtent, and apply it to antecedent conduct?- the Court explained that the Commission had to decide the case before

\footnotetext{
${ }^{35}$ Id at 89.

${ }^{36}$ Id at 92.

${ }^{37}$ In his dissent in Cbenery II, Justice Jackson similarly focused at times on the retroactivity problem of applying a newly minted standard to antecedent conduct and at other times on the quite different problem of the SEC's failure to apply any standard at all to the case before it, relying instead on an ad hoc judgment. See 332 US at 209-18.

${ }^{38}$ See 332 US at 199.

${ }^{39}$ Id at 207-9.
} 
it under proper standards, "regardless of whether those standards previously had been spelled out in a general rule or regulation." As the Court stated: $:^{40}$

$[\mathrm{P}]$ roblems may arise in a case which the administrative agency could not reasonably foresee, problems which must be solved despite the absence of a relevant general rule. Or the agency may not have had sufficient experience with a particular problem to warrant rigidifying its tentative judgment into a hard and fast rule. Or the problem may be so specialized and varying in nature as to be impossible of capture within the boundaries of a general rule. In those situations, the agency must retain power to deal with the problems on a case-to-case basis if the administrative process is to be effective. . . .

Hence we refuse to say that the Commission, which had not previously been confronted with the problem of management trading during reorganization, was forbidden from utilizing this particular proceeding for announcing and applying a new standard of conduct. That such action might have a retroactive effect was not necessarily fatal to its validity. Every case of first impression has a retroactive effect, whether the new principle is announced by a court or by an administrative agency. But such retroactivity must be balanced against the mischief of producing a result which is contrary to a statutory design or to legal and equitable principles. If that mischief is greater than the ill effect of the retroactive application of a new standard, it is not the type of retroactivity which is condemned by law.

As Justice Jackson explained in dissent,${ }^{41}$ this formulation differs significantly from that in Chenery $I$, which had focused at least in part on the rule of law virtues of applying only a rule extant at the time of the governed conduct. The Chenery II opinion, by contrast, expressly approves the retroactive application of a rule announced after the fact by the agency. The question is whether the Chenery II Court, whose explication of the problem of administrative adjudicative retroactivity stands today, adequately addressed the concerns of the Cbenery I Court.

In my view, it did not. Three defenses for the Chenery $I I$ position can be found in the opinion itself. ${ }^{42}$ First: Vague statutory standards often cannot be made meaningful until real, specific cases

\footnotetext{
${ }^{40}$ Id at 202-3.

${ }^{41}$ Id at 209.

${ }^{42}$ I respond to other possible defenses in Part IV.
} 
arise. Agencies must be able to deal with problems on a case-bycase basis, for it is not always possible to know in advance what sort of problems might arise under a vague statutory standard. As I will argue in Parts IV and V, however, one can accommodate this need for evolution of standards either through rulemaking or by permitting rules to be developed through adjudication and applied prospectively only.

Second: The failure to apply the newly announced rule to the antecedent conduct would "produc[e] a result which is contrary to a statutory desigu or to legal and equitable principles." 43 That is, if the agency has determined that the new rule is the proper way of regulating conduct under the statute, but if it is prevented from regulating the conduct in the case before it under such a rule, then that conduct will escape, as it were, the censure it otherwise deserves. But whether the conduct at issue in a particular case should be covered by what the agency considers to be the proper rule of law under the statute is one thing; whether that rule should be applied to conduct predating its announcement is another. Chenery II focuses on the first matter, but does not adequately address the second.

Third: Cbenery II is not blind to the retroactivity problem; it leaves an opening for a balancing test that would consider the harm caused by retroactivity. But the Court did not indicate how such a balance should be struck and has never invalidated an agency balance permitting adjudicative retroactivity. Moreover, the lower courts often grant great deference to an agency's balance. ${ }^{44}$

\footnotetext{
${ }^{43}$ Id at 203.

4t A leading D.C. Circuit case elucidated the balance suggested in Cbenery II by focusing on the following factors: (a) Is this a case of first impression, or does the party that seeks the application of a new rule to antecedent conduct rely on the efforts of an earlier, rule-changing litigant? $(b)$ Does this case overrule a prior case or merely flesh out a statutory provision for the first time? (c) Was there reliance on the prior rule? (d) What burden would retroactivity impose? (e) What is the statutory interest in applying the new rule? Retail, Wbolesale and Dept. Store Union v NLRB, $466 \mathrm{~F} 2 \mathrm{~d} 380$ (DC Cir 1972). Many lower courts have applied the Retail test. See General Am. Transp. Corp. v ICC, 883 F2d 1029 (DC Cir 1989) (petn. for rehearing), cert denied, 493 US 1069 (1990); Soutbwestern Pub. Serv. Co. v FERC, 842 F2d 1204 (10th Cir 1988); NLRB v Wayne Transp., 776 F2d 745 (7th Cir 1985); NLRB v Niagara Mach. or Tool Works, 746 F2d 143 (2d Cir 1984); J.L. Foti Constr. Co. v OSHRC, 687 F2d 853 (6th Cir 1982); Petrolite Corp. v FERC, 667 F2d 664 (8th Cir 1981); E.L. Wiegland Div. v NLRB, 650 F2d 463 (3d Cir 1981), cert denied, 455 US 939 (1982); Maceren $v$ District Director, INS, 509 F2d 934 (9th Cir 1974); California v Simon, 504 F2d 430 (Temp Emerg Ct App), cert denied, 419 US 1021 (1974).

As a result of a Supreme Court case following Cbenery II, NLRB v Bell Aerospace Co., 416 US 267 (1974), the D.C. Circuit has recently construed the Retail balancing test as requiring
} 
Thus, the Cbenery II Court did not adequately deal with the fact that law had "stopped" with the "fair and equitable". and "detrimental to the interests" statutory standards, and had begun again when the SEC fleshed out those standards with a categorical rule that had not previously existed. Where law stops with vague statutory standards, there law begins again with the agency's fleshing out of those standards; if the rule against retroactivity properly applies to legislation, it ought to apply to administrative adjudication that is functionally equivalent to legislation as well.

\section{B. A NEW LAW OF ADMINISTRATIVE ADJUDICATIVE RETROACTIVITY:} APPLYING THE CHEVRON MODEL

Both the delegation doctrine, as applied, and Cbevron reveal, unmistakably, the degree to which the Court acknowledges and accepts the broad lawmaking function of administrative agencies. Although the delegation doctrine formally forbids Congress from delegating legislative power, in practice the Court has permitted just such delegation. Although the Court still requires statutes to state an "intelligible principle" for the agency to follow, ${ }^{45}$ the Court has approved statutory standards requiring agencies to make rules "in the public interest" or to prohibit "unfair methods of competition." 46 Thus, it is fairly clear that almost any statutory standard, no matter how vague or general, will suffice. To be sure, the Court sometimes construes a delegation of power narrowly, ${ }^{47}$ under the theory that Congress would speak more clearly if it truly meant to delegate more broadly, or pursuant to the interpretive canons that

a strong presumption of adjudicative retroactivity with an "abuse of discretion" safety valve. General Am. Transp. Corp. v ICC, 872 F2d 1048 (D.C. Cir 1989), cert denied, 493 US 1069 (1990); see also Russell Weaver, Cballenging Regulatory Interpretations, 23 Ariz St L J 109, 146 (1991); Note, The National Labor Relations Board's Proposed Rules on Healtb Care Bargaining Units, 76 Va L Rev 115, 155-56 (1990) ("Since Bell Aerospace, both the Supreme Court and the circuit courts have shown continued reluctance to interfere with an administrative agency's choice of rulemaking or adjudication"). Courts sometimes say that "manifest injustice" must be shown to overcome the retroactivity presumption. See General Am. Transp. Corp. v ICC, 872 F2d 1048 (DC Cir 1989), cert denied, 493 US 1069 (1990); Montgomery Ward \& Co. v FTC, 691 F2d 1322 (9th Cir 1982); Natural Gas Pipeline Co. v FERC, 590 F2d 664 (7th Cir 1979).

See also notes 13 and 14 .

${ }^{45}$ See Touby $v$ United States, 111 S Ct 1752, 1756 (1991); see also J.W. Hampton, Jr., \& Co. $v$ United States, 276 US 394, 409 (1928).

${ }^{46}$ Sce New York Central Securities Corp. v United States, 287 US 12 (1932); FTC v Gratz, 253 US 421 (1920).

${ }^{47}$ See Industrial Union Dept., AFL-CIO v American Petroleum Inst., 448 US 607 (1980). 
dictate narrow construction to avoid reaching a constitutional question or invalidating a law on constitutional grounds. But for the most part the Court has allowed the practice of delegating to agencies sweeping lawmaking power barely constrained by statutory standards.

Chevron also shows that agencies possess a great swath of judicially sanctioned legislative power. In Chevron, the Court approved a two-stage process for evaluating whether an agency has correctly construed a statute. At the first stage, a court reviewing an agency's statutory interpretation must determine, using traditional tools of statutory construction to ascertain congressional intent, whether there is a proper answer to the issue at hand. ${ }^{48}$ Here, the agency's interpretation is but one (albeit important) piece of evidence regarding the statute's meaming. At this stage, a court determines how far down the law reaches, as it were; in other words, a court determines the parameters of statutory coverage from the available evidence of congressional intent. At some point, there will be insufficient evidence of congressional intent to reach an understanding of whether the statute covers the case at hand. Then, at the second stage, interpretation of the statute-that is, application of the statute to specific settings as to which the normal sources of interpretation are silent-falls to the agency, whose interpretation the court must accept so long as it is reasonable. ${ }^{49}$ At the end of Cbevron, the

\footnotetext{
${ }^{48} 467$ US at 842-45 \& $\mathrm{n} 9$. The debate on the Court regarding the nature of stage 1 Cbevron review involves two interrelated issues: (1) If a statute is "susceptible of two meanings," Young v Community Nutrition Inst., 476 US 974, 988 (1986) (Stevens dissenting), may the agency choose between the possible meanings, even if the court thinks one meaning is a better construction of congressional intent? (2) To what extent should the reviewing court look to legislative history and other nontextual sources to ascertain congressional intent? Although more stage 1 answers will lead to more retroactivity under my model, I need not in this article take a position on these questions.

49 I deliberately avoid the terms "question of law" and "mixed question of law and fact," because one cannot categorize a question as one or the other merely by examining the question itself. See Levin, 74 Georgetown L J at 27-29 (cited in note 6). All questions involving statutory interpretation are initially questions of the following sort: Can we ascertain congressional intent on the question? If we cannot ascertain congressional intent on the question, what we are often left with is the application of a vague statutory term to a particular factual setting. At this point, it is appropriate to defer to the agency's interpretation. But we defer not because the question is one of "law application" rather than a "purely legal question." Rather, we defer because Congress has not answered the question, and beeause it is better (for reasons I need not discuss here) for an agency than a court to make the ensuing policy choice, i.e., to pronounce what the law shall be (made by the agency) after the law (made by Congress) has stopped. See 467 US at 864-66; see also Henry Monaghan, Marbury and the Administrative State, 83 Colum L Rev 1, 29-30 (1983). This is so whether or not Congress actually chose to delegate policymaking authority to the agency. See 467 US at 865.
} 
Court rather candidly explained that when it cannot find an answer to a statutory question according to congressional intent (stage 1), it is appropriate to conclude that the question is one of policy for the agency to decide (stage 2). ${ }^{50}$ In short, at stage 1 , a court determines the meaning of the law to the extent possible given the standard sources of law, and forbids the agency from acting outside the scope of such meaning. But at stage 2 law has stopped, as it were, and discretion takes over; ${ }^{51}$ here, the agency may (and, indeed, must) flesh out the statute on its own, for there is no antecedent source of law prescribing the result.

The underenforced delegation doctrine and the second stage of the Chevron interpretive process reveal that the Court has approved agency power to prescribe, in the first instance, the specific commands to which citizens must conform. Insofar as agencies issue such commands through informal (notice and comment) rulemaking procedures, and apply those commands prospectively, there is no rule of law problem. But as we can see from Chenery $I I$, the Court has approved the retroactive application of new legal standards, so long as this occurs through adjudication rather than rulemaking. If we are troubled by legislative retroactivity, though, then we ought to be troubled as well by the retroactive application of an agency policy choice unconstrained by congressional intent.

Examining Cbevron in greater detail reveals the flaw in Cbenery II. For even though Chevron is methodologically part of a line of cases regarding judicial review of agency statutory interpretation that includes Chenery $I I,{ }^{52}$ it clarifies the connection between the absence of interpretive constraints and the fact of agency lawmaking. As I have explained above, Chevron requires courts to review agency statutory interpretation by conducting a de novo examination of traditional sources of congressional intent-text, structure, history. When the courts conclude from such a review that the seemingly vague or ambiguous term in fact has a proper meaning, then that is the meaning the agency must follow. It is precisely in these Cbevron stage 1 cases that we should permit agencies to apply

\footnotetext{
${ }^{50} 467$ US at $865-66$.

${ }^{51}$ See Kenneth Davis, Discretionary Justice: A Preliminary Inquiry 21 (1969) ("Where law ends individualized justice begins").

${ }^{52}$ Recall that in Chenery II the Court gave great deference to the SEC's "interpretation" of the statute.
} 
adjudicative rules retroactively, for if the courts can discover a proper meaning from an evaluation of traditional sources of congressional intent, then so can the affected citizens.

There are, however, cases in which the courts conclude that there is no proper answer to a question of statutory interpretation, that the legislature left the matter open, either explicitly or implicitly, ${ }^{53}$ to be decided by the agency. Chevron candidly acknowledges that Congress sometimes leaves to agencies the determination of policy: ${ }^{54}$

In these cases, the Administrator's interpretation represents a reasonable accommodation of manifestly competing interests and is entitled to deference: the regulatory scheme is technical and complex, the agency considered the matter in a detailed and reasoned fashion, and the decision involves reconciling conflicting policies. Congress intended to accommodate both interests, but did not do so itself on the level of specificity presented by these cases. ...

... [A]n agency to which Congress has delegated policynaking responsibilities nuay, within the linits of that delegation, properly rely upon the incumbent administration's views of wise policy to inform its judgments. While agencies are not directly accountable to the people, the Chief Executive is, and it is entirely appropriate for this political branch of the Government to make such policy choices .... .

When a challenge to an agency construction of a statutory provision, fairly conceptualized, really centers on the wisdom of the agency's policy, rather than whether it is a reasonable choice within a gap left open by Congress, the challenge must fail.

In Chevron, the Court was unable to resolve at stage 1 the statutory interpretation question presented by examining the traditional sources of legislative meaning. So the Court moved on to the second stage of analysis, concluding that Congress had given the agency the responsibility of fleshing out an otherwise unclear statutory term, that the agency, in other words, had become the lawniaker after Congress had started the ball rolling. Although dubbing the agency the "lawmaker" is in tension with the formal view

${ }^{53}$ See 467 US at 865 . As Judge Breyer has pointed out, "Congress is rarely . . explicit about delegating the legal power to interpret a statute." Stephen Breyer, Judicial Review of Questions of Law and Policy, 38 Admin L Rev 363, 369 (1986).

${ }^{s+} 467$ US at $865-66$. 
of legislative delegation, it fits with the Court's underenforcement of the delegation doctrine, and helps show how once law stops (a court cannot discover congressional intent regarding a certain type of problem) there law begins again (the next-in-line governmental actor, the agency, may say what the law is). ${ }^{55}$ If a question of statutory interpretation is resolvable only at this second stage, as a matter of agency policy choice, of agency lawmaking, then, in keeping with the norın against legislative retroactivity, we should not allow the announced rule to apply retroactively.

The point here is an important one, revealing the link between adjudicative constraints and notice, and thus helping to show how we can adjust the $C b e n e r y I I$ principle of administrative adjudicative retroactivity to accommodate rule of law values. Chevron's lesson is more than just that Congress sometimes leaves important lawmaking functions to agencies. The further lesson of Chevron is that it is appropriate for agencies to be lawmakers only when the available sources for determining congressional intent-for determining what the law is-are inadequate to the task. It is here that we can see the firm connection to the concerns of the rule of law, because the sources that constrain agency adjudicators in determining what the law means are precisely the same sources that give citizens notice of their legal obligations. If an agency adjudicator or court can determine a proper answer to a question of statutory interpretation from an evaluation of traditional sources of congressional intent, then citizens too are on notice of congressional intent regarding the question, for they can evaluate the same sources examined by the agency or the court. However, if the interpretive question is resolvable not froin examining sources of congressional intent, but instead only by an agency policy choice made at the time of the adjudication, then citizens are not on notice of the source of law that governs until the agency announces its policy choice. ${ }^{56}$

\footnotetext{
${ }^{55}$ Whether there is congressional "law" to apply or whether an agency may act in a fairly unfettered manner in creating the "law" is a question that arises in a slightly different posture in cases interpreting APA $\$ 701(\mathrm{a})(2)$, which renders the APA judicial review chapter inapplicable "to the extent that agency action is committed to agency discretion by law." See Heckler v Cbaney, 470 US 821 (1985); Citizens to Preserve Overton Park, Inc. v Volpe, 401 US 402 (1971); see also Cass Sunstein, Reviewing Agency Inaction After Heckler v Cbaney, 52 U Chi L Rev 653 (1985).

${ }^{56}$ Cf. Harry Wellington, Common Law Rules and Constitutional Double Standards: Some Notes on Adjudication, 83 Yale L J 221, 242-43 (1973) (retroactive application of an adjudicative rule may be problematic if the policy of the governing statute "could have been effectuated
} 
Thus, Cheoron both (a) acknowledges that agencies make law, and (b) provides a device for determining when administrative adjudicative retroactivity is permissible and when it is not. Rules developed through administrative adjudication will sometimes be properly based in extant sources of law, but will at other times represent a relatively unconstrained choice by the adjudicator. As the Chevron two-stage process reveals, we have the means to determine on which side of this line a case falls. ${ }^{57}$

Unfortunately, form often obscures function in our thinking about administrative adjudicative retroactivity; in particular, consider the sharp distinctions often drawn between rulemaking and adjudication in admimistrative law. Informal rulemaking looks like congressional lawmaking-the notice and comment process is the administrative analogue to congressional hearings, bill mark-ups, and floor debates. Accordingly, restrictions on retroactive rulemaking are strict. Admimistrative adjudication, on the other hand, looks like a process for applying law to fact, for merely deciding a case; thus, retroactive adjudication is the norm. But this focus on the

in a number of ways and . . there was nothing in prior published decisions or regulations to suggest that a rule extinguishing [a right of one of the parties] was to be the chosen instrument for furthering the policy. This problem of potentially alternative mles (and, therefore, of discretion) available to a decisionmaker is endemic to rules justified by policies").

${ }^{57} \mathrm{My}$ discussion here has focused on statutory interpretation by administrative agencies. The Cbevron model is predicated on the belief that ascertaining congressional intent (or, perhaps, statutory "purpose") is the appropriate task for adjudicators engaged in statutory interpretation. I need not discuss here the question of which constraints are appropriate in common law adjudication. Likewise, I need not now consider the application of the Cbevron model to the fleshing out of vague constitutional commands, and mention now only a few possible concerns. Whether constitutional interpretation should rest on an originalist premise, of ascertaining the framers' intent, is a difficult and controversial question. Also, in the constitutional setting especially, one might contend that adjudicative retroactivity helps support the proposition that we are a "government of laws, not men," a proposition that perhaps bolsters public support for the judicial system. See Paul Mishkin, Foreword: Tbe High Court, The Great Writ, and the Due Process of Time and Law, 79 Harv L Rev 56, 60-70 (1965). This theory is problenuatic, however, in part because it is not clcar that people actually believe we are a government of laws, not men. Cf. Jerome Frank, Law and tbe Modern Mind 36 (1930) (niyth that judges don't make law "lcads, sooner or later, to a distrust of the judges, a disrespect for their opinions").

There is one other type of case to address: When a court interprets a statute without a prior agency interpretation, the Cbevron model should still apply (unless Article III of the Constitution requires a different result, see note 97). That is, if the court can determine the correct answer to the interpretive question at the equivalent to stage 1 of Cbevron, it niay apply the resulting rule retroactively. Conversely, if the court itself must make what is the equivalent of a stage 2 Cbevron policy choice (which it nust do absent an agency choice to which it can defer), then the resulting rule should not be applied retroactively. 
applying-the-law, deciding-a-case part of adjudication obscures the pure lawmaking that agency adjudicators do.

To understand how the problem of form obscuring function might arise in practice, consider the following variations on Chevron and Cbenery II. In Chevron, Congress had permitted a maximum amount of pollution from a "stationary source"; the question was whether this term required each pollution-emitting device in a plant to emit no more than the maximum level of pollution, or whether an entire plant could be considered a "stationary source," thus permitting a company to credit the under-pollution from some devices against the over-pollution from others. The EPA issued a regulation adopting the latter interpretation; after determining that there were insufficient sources of congressional intent to resolve the question, the Court upheld the regulation, concluding that Congress had left the policy choice to the agency.

But what if Cbevron had arisen in the course of an EPA enforcement proceeding against a polluter for emitting too much pollution from a single device; the polluter had defended by arguing that its entire plant-wide pollution should be considered; and the EPA had rejected that argument, determining instead that "stationary source" refers to each device, and not the entire plant? On Chevron's logic, this interpretation (the opposite of the one the EPA actually chose) should be upheld, because Congress left the lawmaking choice to the agency. Under the Chenery II rule permitting adjudicative retroactivity, the polluter could be penalized for a choice that was proscribed after the fact, not before. But this result doesn't seem correct; because Chevron approves agency lawmaking, we should be concerned about the retroactivity of such "laws" just as we are concerned about the retroactivity of Congress' laws.

Now consider a variation on Cbenery II: The SEC announced a new principle through adjudication, namely, that management may not trade in the shares of its own corporation during reorganization. The agency applied this principle to the parties by ordering the stock surrendered to the corporation. Thus, it applied a new principle (a gloss on a vague statutory term) retroactively. But what if the SEC had proceeded by rulemaking instead of adjudication, and had promulgated the same no-trading rule? Under the accepted norm disfavoring retroactive rulemaking, that rule could not be applied retroactively. Why should an agency be permitted to apply new law retroactively in one instance and not in another? 
Shifting focus from form to function also raises a tantalizing question about agency rulemaking: We accept the nonretroactivity of informal administrative rulemaking without serious question, in part because of the APA's text, ${ }^{58}$ but also because of the legislative form of such rulemaking. But under the Chevron model for choosing between retroactivity and nonretroactivity in administrative adjudication, rulemaking rules as well as adjudicative rules should be applied retroactively if they follow from congressional intent as a Chevron stage 1 matter. Agency rulemaking is not perfectly analogous to congressional legislation for retroactivity purposes, because while the source of authority for congressional legislation, the Constitution, generally does not compel any particular legislation; statutes sometimes do compel the agency to adopt certain rules. If an agency adjudicator may properly apply an adjudicative rule retroactively because it follows from congressional intent, then perhaps an agency rulemaker should be permitted to apply a rulemaking rule retroactively in similar circumstances. ${ }^{59}$

In the $1990 \mathrm{Term}$, in an otherwise minor, uncontroversial case, the Court revealed how far the fact of agency lawmaking has penetrated the judicial mind, even as judges strain to retain the formal theory of agency-as-law-applier. In Martin v Occupational Safety and Health Review Commission, ${ }^{60}$ the Court unanimously held that when the Secretary of Labor and the Commission disagree as to the meaning of a regulatory term, the reviewing court must defer to the Secretary rather than the Commission. The decision turned prinarily on the unusual nature of the Commission, which Congress split off from the Department of Labor to ensure an impartial set of administrative law judges who were empowered merely to resolve disputes, leaving to the Secretary the role of fleshing out legislative commands. In the opinion, the Court twice referred to the Secretary's task in fleshing out statutes as "interpretive lawmaking. "6I I have been unable to find any other federal court opinion that has ever used this term. It is a good term, for it nicely describes what agencies do (and are permitted to do) when they nuake sense

\footnotetext{
${ }^{58}$ See note 27 and accompanying text.

59 See the debate in City of Dotban $v$ FERC, 684 F2d 159, 162-63 n 2 (DC Cir 1982); id at 168-69 n 8 (Mikva dissenting).

${ }^{60} 111$ S Ct 1171 (1991).

${ }^{61}$ Id at 1176-77.
} 
of vague statutory terms. It is a term that appropriately describes the agency function as (often) legislative. The Court should carry its descriptive accuracy through to a normative conclusion: Whenever an agency acts as an "interpretive lawmaker," either in its rulemaking or adjudicative capacity, it should be subject to the same rule disfavoring retroactivity as the original, "noninterpretive lawmaker," Congress.

\section{The Affirmative Defenses of Chenery II}

I have criticized the permissive Chenery $I I$ acceptance of administrative adjudicative retroactivity for its failure to recognize the lawmaking role agency adjudicators sometimes play. In doing so, I have not focused on the use of the adjudicative form to develop the law, and the role played by retroactive application in this developnient. In this part, I shall respond to four such affirmative defenses for Chenery II. These defenses acknowledge that agency adjudicators do not always "apply" antecedent law; that is, these defenses do not support Chenery $I I$ on the formalist ground that adjudicative rules should apply retroactively because adjudicators never make law. Rather, the defenses offer a more sophisticated, "realist" fortification for a strong norm of administrative adjudicative retroactivity.

\section{A. THE NEED FOR REGULATORY FLEXIBILITY}

The first defense of Chenery $I I$ acknowledges that the values of the rule of law might be impaired in some instances by applying adjudicative rules retroactively, but offers countervailing values to offset the damage to the rule of law. On this view, courts and agencies must have the power to develop new rules through adjudication and apply them retroactively because it is the courts and agencies, and not the legislatures, that can respond to specific cases as they arise and to changing societal conditions. ${ }^{62}$ If government may operate by prospectively applied legislative or rulemaking rules alone, then situations will arise in the interstices of those

${ }^{62}$ See SEC v Cbenery Corp., 332 US 194 (1947); Fuller, Morality of Law at 56 (cited in note 7) ("If every time doubt arose as to the meaning of a rule, the judge were to declare the existence of a legal vacuum, the efficacy of the whole system of prospective rules would be seriously impaired"). 
rules that would be ungovernable until the legislature or rulemakers could again assemble and confront the problem. Delay would be harmful in many settings, and in other settings the problems would not be significant enough to warrant legislative or rulemaking response. Only by permitting agencies to fill the gaps through caseby-case development of statutory principles can we respond to the nuanced changes in the social fabric. ${ }^{63}$ Put differently, the stringent demands of the rule of law must be moderated for the sake of social order. The best the legislature or rulemakers can do is issue commands of a general nature; as long as the citizens are on notice of those commands and of the reasonable spectrum of interpretation thereunder, they must do their best to conform their behavior to the likely or possible adjudicative outcomes.

The result of accepting such a theory, however, might be that citizens will conform their conduct to a wide array of possible interpretations of the governing law, to avoid penalties, thereby reducing their spectrum of liberty in planning their lives. Beneath each vague statutory standard, there exists a variety of specific rules that might be permissible interpretations of congressional intent. If there is insufficient evidence of congressional intent to answer the statutory question at Chevron stage 1 , if the agency is empowered to choose which more specific categories are covered and which are not, and if the norm of adjudicative retroactivity applies, then people might conform their conduct to the array of possible administrative "interpretations" rather than wait to see which categories the agency chooses to cover and which not. This overdeterrence is the result of a strong norm of adjudicative retroactivity. ${ }^{64}$

But we can avoid such overdeterrence. For the supposed need to ensure regulatory flexibility through adjudicative retroactivity is overstated. First, substantial regulatory flexibility is afforded by underenforcing the delegation doctrine and permitting what amounts to administrative lawmaking through informal rulemaking procedures. Second, flexibility is advanced by permitting agencies

${ }^{63}$ See Davis, Discretionary Justice at 28-42 (cited in note 51) (values of administrative adjudicative retroactivity include (a) responsiveness to changing conditions, (b) better development of rules case by case, (c) need to resolve disputes, $(d)$ legislative inertia).

${ }^{64}$ See Richard Fallon and Daniel Meltzer, New Law, Non-Retroactivity, and Constitutional Remedies, 104 Harv L Rev 1731, 1792 (1991); J. Skelly Wright, Review: Beyond Discretionary Justice, 81 Yale L J 575, 589 (1972). 
to apply adjudicative rules purely prospectively.$^{65}$ Third, I am not advocating that every adjudicative specification of a general statutory standard may not be applied retroactively; there must be a method for distinguishing those adjudicative rules that were fairly ascertainable in advance by the parties and those that were not. I proposed one such method in Part IIIB.

There is an additional problem, as well. The reductio ad absurdum of the argument for regulatory flexibility is an autocracy, that is, a government in which one person develops the rules as cases arise. To guarantee pinpoint responses to the variety of situations that arise under a statutory scheme, a government would ideally place all power within the hands of one person, who could coordinate responses to the set of cases, and who could act swiftly to ensure no time gap between rules and governed behavior. To some degree, the framers' choice of a unitary rather than a plural executive reflects these concerns with coordination and efficiency (as well as accountability). ${ }^{66}$ But the framers were equally clear about the vices of placing lawmaking powers in the hands of one person; they placed the lawmaking function in the hands of the many rather than the one, and created a cumbersome process for the creation of law. ${ }^{67}$ As the Supreme Court has reminded us, unfettered flexibility is not one of the hallmarks of the American constitutional structure. ${ }^{68}$

\section{B. THE COMMON LAW MODEL}

The preceding argument-that adjudicative retroactivity ensures regulatory flexibility-treats adjudicative retroactivity as a necessary by-product of the administrative state. But one could focus more directly on the common-law virtues of adjudicative retroactivity. The common law tradition backs the interstitial judicial development of such statutory terms as "reasonable," "fair and equitable," etc. According to supporters of common law methodology, case-by-case development of standards is a good thing, be-

\footnotetext{
${ }^{65}$ See Part V.

${ }^{66}$ See Tbe Federalist No 70 (Hamilton).

${ }^{67}$ See US Const, Art I, § 7.

${ }^{68}$ See INS v Cbadba, 462 US 919 (1983); see also Henry Friendly, Tbe Federal Administrative Agencies: The Need for a Better Definition of Standards 20-21 (1962) (flexibility and predictability are inversely related).
} 
cause adjudicators can sometimes develop standards more carefully than can legislators; ${ }^{69}$ because adjudicators, faced with real facts, can distinguish cases, and thus develop subcategories of principle as the occasion warrants; and because adjudicative rulings do not have as broad an impact as statutes, and thus the cost of adjudicative mistakes is less. As the Court put it in Chenery II, "Not every principle essential to the effective administration of a statute can or should be cast immediately into the mold of a general rule. Some principles must await their own development, while others must be adjusted to meet particular, unforeseen situations." ${ }^{70}$ All adjudication is, in a sense, a form of common law development of standards-c"rules are a kind of by-product of the adjudicative process"71 - and adjudicative retroactivity is descriptive of the value of having one's conduct governed in the best possible fashion, by rulings tailored to the equities of the case at hand. ${ }^{72}$

The norm of adjudicative retroactivity might well be a product of our common law tradition. Common law courts combine the adjudicative and legislative functions. They consider both what the law is and what the law will be. The notion of a "developing" body of law captures this confluence. Thus, when a conimon law court announces a new rule but explains its pedigree in old rules, applying the new rule retroactively makes sense. ${ }^{73}$ But when a common law court overrules its own precedent or announces a rule

\footnotetext{
${ }^{69}$ See Davis, Discretionary Justice at 20-21 (cited in note 51 ).

70332 US at 202.

${ }^{71}$ Lon Fuller, Adjudication and the Rule of Law, Proc Am Soc of Int'l L 6 (1960).

${ }^{72}$ For example, although advocating generally that "legal newness is best analyzed as a matter of a decision's relative predictability," 104 Harv L Rev at 1794 (cited in note 64), Professors Fallon and Meltzer ultimately adopt a more specific definition of new law, approving new law trcatment for claims that were "not 'clearly foreshadowed' by precedent," but "exclud[ing] instances of ordinary legal evolution." Id at 1796; see id at 1817. In other words, "legal rules and principles are new to the extent that, ex ante, their recognition as authoritative would have been viewed as relatively unlikely by competent lawyers." Id at 1763. If an adjudicative rule does not represent a "clear break with the past" (such as an overruling case), such a rule should be denied retroactive application only if it "lacks the kind of foreshadowing that characterizes ordinary legal evolution." Id at 1831. Fallon and Meltzer's definition (although not applied by them to the administrative law setting) would seem to exclude from new law treatment the fleshing out of vagne statutory standards, i.e., their definition would consider fleshing-out rules as worthy of normal, retroactive application.

${ }^{73}$ The retroactivity norm of the common law exists in large part because many cases are "easy," i.e., decidable deductively fron preexisting law. See Currier, 51 Va L Rev at 241 n 122 (cited in note 18); Lon Fuller, The Forms and Limits of Adjudication, 92 Harv L Rev 353,392 (1978).
} 
that cannot reasonably be said to be an outgrowth of prior rules or of other legal constraints, the norm of adjudicative retroactivity is on shaky ground. Put another way, common law courts do not "make up" the law as legislatures may "make up" the law; it is wrong to view the common law as merely a rolling act of judicial creativity. ${ }^{74}$ Rather, judges acting in a common law capacity must seek to fit their rulings with the social understandings of the day, to capture "common" behavior in the "common" law. ${ }^{75}$ A common law ruling that surprises people whose behavior it governs would, in departing from the core notion of common law constraints, be untrue to the common law pedigree, especially if applied retroactively. ${ }^{76}$

Thus, we can distinguish three types of case facing administrative adjudicators. First, some statutory standards recognize the difficulty of developing more finely honed rules, and leave to the case-by-case decisionmaking process the application of these standards. For example, adjudication under a statutory standard requiring "reasonable" conduct might, like its common-law cousin, generally fail to foster interstitial rules that would then serve as precedent for later cases. ${ }^{77}$ Rather, the standard might itself be recognized as the final statement of law, which is then left for case-by-case application. But we accept such law-applying not because we want or expect the decisionmaker to decide cases in an unconstrained manner. Rather, we expect the decisionmaker applying a standard such as "reasonable" to be guided by accepted behavioral norms of the relevant community.

${ }^{74}$ "Over much of its history the common law has been largely engaged in working out the implications of conceptions that were generally held in the society of the time. This large measure of coincidence between moral and legal demands reduced greatly the force of the objection that the rules of the common law were, in contrast with those of a code, difficult of access." Fuller, Morality of Law at 50 (cited in note 7).

${ }^{75}$ See Mishkin, 79 Harv L Rev at 60 (cited in note 57); Stephen Munzer, Retroactive Law, $6 \mathrm{~J}$ Legal Stud 373, 376 (1977); Wellington, 83 Yale L J at 236 (cited in note 56); id at 256 ("changing morality that is there and knowable to the normal adult is filtered through existing common law doctrine"). This is why it makes sense to say that adjudicative precedent "binds" the citizens just as laws do. See NLRB v Wyman-Gordon Co., 394 US 759, 769 n 1 (1969) (Black concurring in the result).

${ }^{76}$ The attempt to constrain adjudication to extant sources of principle is the source of the administrative law requirement that agencies explain consistency with precedent. See $S E C$ $v$ Cbentery Corp., 318 US 80 (1943); Richard Berg, Re-Examining Policy Procedures: Tbe Cboice Between Rulemaking and Adjudication, 38 Admin L Rev 149, 162 (1986).

7 For exceptions to the generalization, see Stephen Gilles, Rule-Based Negligence and tbe Regulation of Activity Levels, $21 \mathrm{~J}$ Legal Stud (Forthcoming) (1992). 
In a second type of case, the administrative agency might announce in the adjudication a previously unannounced rule of law developed under a statutory standard that did not spell out the rule. But, acting in similar fashion to the decisionmaker in the first case, the adjudicator in this second case would carefully explain how the announced rule followed from congressional intent, that is, that its choice was not just one among many policy positions, but rather was compelled by a legally constraining norm. ${ }^{78}$ Here, then, the announcement and application of a rule in the administrative adjudication, although different from the first case by virtue of being a categorical pronouncement with intended precedential value, is nonetheless similar to the first case by relying on a source of legal constraint.

The third type of case is similar to the second in that the adjudicator announces rules that had been previously unannounced. But unlike both of the prior types of case, in this third type of case the adjudicator derives the rule not from an accepted pool of legal constraints, but rather from the less-constrained world of "policy" preferences. That is, the decision is based on what the adjudicator thinks will lead to a better social outcome. These decisions will not be "unconstrained" in the sense of being arbitrary; they will, that. is, be based on familiar arguments about social good. But one agency's theory of the good might differ drastically from another's, often depending upon the administration controlling the White House at the time. ${ }^{79}$ The policy choices made in this third type of case will be those sorts of choices that courts leave to agencies at stage 2 of the Chevron test. They are not true to the common law form.

\section{WHO BEARS THE RISK OF UNCERTAINTY?}

One might contend that $I$ have assumed without argument that the party that would gain from a new adjudicative rule must bear

\footnotetext{
${ }^{78}$ I have focused on congressional intent as a source of legal constraint, for that is Cbevron's focus. An agency adjudicator might also be constrained by prior agency precedent or regulation, even if the precedential rule or regulation was not itself required by congressional intent as a stage 1 Cbevron matter. When adjudicative rules should be applied retroactively because of a basis in precedent is a difficult matter that I do not address here. Similarly, I bracket the related issue of an agency's following its own regulations.

${ }^{79}$ See Cbevron, U.S.A., Inc. v Natural Resources Defense Council, Inc., 467 US 837, 865-66 (1984).
} 
all the risk that such a rule was uncertain to follow from the statute. Assume both parties to a transaction know they are within the realm of a particular statutory term, and both know that the term is currently vague. They believe that different interpretations of the term are correct, and they order their affairs accordingly. An adjudicator then decides that the vague rule "means" what one party says it means. Under my analysis in Part IIIB, the rule should not apply to the other party's behavior if that party had insufficient reason to know the rule "meant" what the adjudicator later said it meant - that is, if the adjudicator's choice turned out to be a policy choice unconstrained by congressional intent. But this seems to beg the question of which party should bear the risk that its guess as to what the law means is wrong; my analysis always places the risk on the winning party. ${ }^{80}$

My proposal is consciously grounded in a baseline of existing wealth distribution. ${ }^{81}$ Taking away someone's wealth is a disruption of the status quo, requiring special justification. The party who argues that a rule of law operates to deprive another party of held wealth bears the burden of showing that the rule was sufficiently knowable in advance of the other party's primary conduct that is in question. In other words, the argument that the party hurt by the new rule should bear (or share) the risk of the uncertain application of the statute ignores the value of the settled expectation of the status quo, which holds unless ruptured by a prospective rule.

It might be easier to see how this position is reached by recalling how the rule of law results in the norm of legislative prospectivity. Consider this situation: I refuse to hire some people merely because of their excessive weight; no law prohibits such refusal to hire. The next day the government enacts such a law and purports to apply it to my antecedent conduct. Now one could say that there was a

\footnotetext{
${ }^{80}$ Cf. Aliceville Hydro Associates v FERC, 800 F2d 1147, 1152-53 (DC Cir 1986).

${ }^{81}$ For an argument that the principle against retroactive legislation should be relaxed in the face of "a distribution that does not conform to the pattern prescribed by justice," see Stephen Munzer, A Theory of Retroactive Legislation, 61 Tex L Rev 425, 436 (1982); see also William Eskridge, Jr. \& Philip Frickey, Cases and Materials on Legislation: Statutes and the Creation of Public Policy 263-64 (1988) (statutes sometimes "have great continuity with the pre-existing legal landscape," and "must sometimes be retroactive in order to get at the problems they attack"); Mishkin, 79 Harv L Rev at 70 (cited in note 57) ("if the old law is clearly unjust or immoral by community standards . . . , reliance upon it should not be considered justified, and a court should feel no inhibitions about adopting a new rule"); Rawls, Theory of Justice at 242-43 (cited in note 9).
} 
"risk of uncertainty" regarding whether such an ordinance would be enacted. But to say I should bear a portion of that risk by paying for antecedent conduct would make a mockery of the values of the rule of law discussed in Part II.

In other words, we do not require both parties to a redistribution of wealth to bear some of the risk of uncertainty that new laws will be applied retroactively. We accept (and, indeed, admire) the liberty that follows from being able to plan one's conduct under the extant legal regime. One must still, of course, account for and bear the risk of the uncertain application of the legal rules that currèntly exist. But stage 1 Cbevron cases involve just such situations: Many laws that are not crystal clear will, nonetheless, properly apply to antecedent conduct, for sufficient constraints will exist for both the adjudicator and the citizeh to understand what those laws mean in the relevant situation. Applying the rule of a stage 2 Cbevron case to antecedent conduct, however, is functionally identical to applying a congressional law retroactively, and should be disfavored for the same reasons we disfavor retroactive legislation. We should not require the party that the new adjudicative rule would harm to share the risk of uncertainty any more than we require a citizen to share the risk of uncertainty that new law will be applied retroactively. We operate under a strong (though not absolute) norm of legislative prospectivity, because although we accept the prospective regulation of the status quo of wealth distribution, ${ }^{82}$

\footnotetext{
${ }^{82}$ Accepting the status quo wealth distribution as a baseline for placing the risk of a retroactive disruption on the advantaged party says nothing about the virtues or vices of laws affecting wealth allocation prospectively. Although such laws may also upset the status quo wealth distribution, they do not impair settled expectations by redefining the legal status of past transactions or conduct as retroactive laws do.

One might object that even prospective wealth redistribution might upset reliance interests based on the prior legal regime; people might not have invested in a certain sort of property, for instance, had they known that the property would be subject in the future to more restrictive zoning regulations. But it may be possible to acknowledge a difference between primary and secondary retroactivity. See Bowen $v$ Georgetown Univ. Hosp., $109 \mathrm{~S} \mathrm{Ct}$ 468, 477 (1988) (Scalia concurring); Munzer, 61 Tex L Rev at 426 (cited in note 81); but see generally Richard Epstein, Takings: Private Property and tbe Power of Eminemt Domain (1985). We could, perhaps, apply a strong rule against primary retroactivity only; i.e., we could ensure that rules do not alter the legal status of prior acts. Were we to forbid secondary retroactivity as well-i.e., any new rule that affected the value of prior investmentslegislation would be hard to come by. See Hochman, 73 Harv L Rev at 701 (cited in note 10) (discussing comment of Justice Holmes in Pennsylvania Coal Co. $v$ Mabon, 260 US 393, 413 (1922)); Shapiro, 78 Harv L Rev at 934 (cited in note 28). All I mcan to do here is apply my analysis to primary retroactivity; I need take no position now regarding whether secondary retroactivity can be successfully distinguished.
} 
retroactive legislation is thought to be in significant tension with values of the rule of law. We should do the same for administrative adjudication that is properly labeled a "policy choice."

We might distingnish three types of situation in which the administrative adjudicative retroactivity problem would arise. First, there are cases in which the government brings an enforcement action against a private party. In these cases, any talk of "sharing the risk of uncertainty" seems out of place. It is awkward to talk of the government as having a reliance interest. Furthermore, in the public law settings with which this article is concerned, the government is parceling out the packages of rights and duties; it is not the recipient. Finally, the singling-out problem that exists in cases with two private parties disappears when the government is acting in its enforcement capacity. In a case with two private parties, the party that is favored by the new adjudicative rule--but that would not receive the benefit of its application under my theory-must bear the cost of the risk of uncertainty. But the government serves as a collective pooler of risk; even in its capacity of protecting public values against the intrusion of certain private interests, the government can spread widely among the citizens the cost of the risk of uncertainty.

Second, there are cases in which two private parties are involved, the statutory term at issue is vague, and the rule the adjudicator thinks best to decide the case is of the Chevron stage 2 variety, that is, it is an agency policy choice not mandated by congressional intent. Here, the case is functionally identical to a case of retroactive lawmaking: Forcing the party that would benefit from retroactive application to bear the risk of uncertainty generated by the unclarity of the statutory term is precisely like requiring a party that would benefit from retroactive application of a congressional law to bear the risk of uncertainty that the law would be enacted, a risk we permit without question.

The third set of cases is the hardest for my model: Here, private parties dispute the meaning of a statutory term that, although unclear and without a stage 1 Chevron answer, nonetheless admits of only a few, rather than many, possible meanings. ${ }^{83}$ Consider again the variation on Cheoron discussed near the end of Part IIIB. Assume for now that a damages remedy is potentially available to

${ }^{83}$ One might consider this a case of ambiguity; the prior type of case, one of vagueness. 
plaintiff, NRDC. The dispute is whether the term "stationary source" means a particular pollution-emitting device or an entire plant of such devices. Other interpretations are not available. Thus, unlike the second type of case, in which the agency chooses from a broad range of options under a wide-open standard, when the agency is choosing from options that are few in number and known by both parties to be options, one might contend that each party should bear some of the risk of the uncertainty of how the term would be applied.

But even in this setting, the agency choice between the two options is, as a stage 2 Chevron matter, a policy choice not constrained by congressional intent. Consider as an analogy this situation: A set of companies is polluting in an environment currently unregulated by either statute or regulation. Congress is considering two options: (a) permitting $\mathrm{X}$ level of pollution from each smokestack, or $(b)$ permitting Y level of pollution from each plant, or set of smokestacks. The polluters and the environmental litigation groups know that if Congress enacts (a), these polluters will have to pay fines if they continue polluting, but that if Congress enacts (b), these polluters will be within the legal limits. If Congress enacts (a), and seeks to impose fines for past as well as future pollution, we would say that values of the rule of law have been impaired by retroactive legislation, even though the polluters knew that the legislative options were limited and knew that one of the two choices would cover their plants. By analogizing stage 2 Chevron cases to the congressional setting, we can again see the flaws with the risk-sharing argument. ${ }^{84}$

\section{INCENTIVES TO LITIGATE}

Finally, one might object that were adjudicators forbidden from applying new rules retroactively, the developinent of the law would stultify because plaintiffs ${ }^{85}$ seeking the amouncement of new law

\footnotetext{
${ }^{84}$ Even if one adopted the risk-sharing argument in the third type of case, one could still adopt my model in the first two types of case, and even in the third case, one could impose only that proportion of retroactive liability that represents the polluters' share of the risk of uncertainty.

${ }^{85}$ Conceivably defendants, once dragged into litigation, might also advocate the fleshing out of vague statutory standards, but because defendants are already party to litigation against their will, there is little reason to believe that adopting my theory of adjudicative retroactivity would deter them from urging new rules in their responsive pleadings.
} 
under vague standards would have no incentive, or a reduced incentive, to bring such litigation, knowing that the adjudicators would not apply a new rule retroactively. ${ }^{86}$ Thus, the application of new adjudicative rules to antecedent conduct helps ensure that statutory standards are properly developed. ${ }^{87}$

But there are several reasons why we should not be concerned that limiting adjudicative retroactivity will excessively deter litigation that seeks to develop new rules. First, many cases that currently result in the announcement of a new rule are not brought by the plaintiff with that purpose in mind. Plaintiffs might think they can win at Chevron stage 1 -that the rule they advocate is the proper reading of congressional intent, not merely one of a number of policy choices the agency is permitted to make. ${ }^{88}$ Only when plaintiffs seek rules that they know are not resolvable at stage 1 of Cherron will the possibility of nonretroactivity create a disincentive for litigation.

Second, plaintiffs who have an interest not only in recovering damages or in undoing a past transaction, but in affecting the future state of affairs as well, will still have a strong incentive to sue, for a relaxed norm of adjudicative retroactivity might still permit the adjudicator to apply a new rule prospectively only. This category of plaintiff includes those seeking injunctive or declaratory relief as well as institutional plaintiffs who see the same sorts of issues arise a number of times. In short, any "repeat player" might still seek legal change through adjudication. ${ }^{89}$

Third, our legal system already includes the qualified immunity doctrine, which deters suits against government officials that might

${ }^{86}$ See, for example, Mackey $v$ United States, 401 US 667, 675 (1971) (Harlan concurring in the judgment); Stovall v Denno, 388 US 293 (1967); Albert Alschuler, "Close Enougb for Government Work": The Exclusionary Rule After Leon, 1984 Supreme Court Review 309, 340 41; Fallon and Meltzer, 104 Harv L Rev at 1804 (cited in note 64); Fuller, Morality of Law at 57 (cited in note 7); Mishkin, 79 Harv L Rev at 60-62 (cited in note 57); Note, 71 Yale L J at $945 \mathrm{n} 192$ (cited in note 9).

${ }^{87}$ This problem would not exist, of course, when the government is the plaintiff, for it can always institute a rulemaking proceeding to enunciate a new rule. See Vermont Yankee Nuclear Power Corp. $v$ NRDC, 435 US 519, 528 (1978) (government spots unresolved issue in adjudication and begins rnlemaking to resolve it).

${ }^{88}$ Cf. Currier, 51 Va L Rev at 215 (cited in note 18); Fallon and Meltzer, 104 Harv L Rev at 1806 (cited in note 64); Mishkin, 79 Harv L Rev at 61 (cited in note 57).

${ }^{89}$ See Currier, 51 Va L Rev at 215 (cited in note 18); Fallon and Meltzer, 104 Harv L Rev at 1804 (cited in note 64); Fuller, Morality of Law at 57 (cited in note 7). 
change the law or declare a new principle. ${ }^{90}$ Under current qualified immunity principles, individual governniental actors cannot be held personally liable in damages for acts that might later be deenied unconstitutional, if a reasonable government official would have believed that the acts were constitutional. ${ }^{91}$ Thus, the system already has a built-in deterrent to using adjudication to penalize people acting with the reasonable belief that their conduct was lawful. Limiting adjudicative retroactivity fits within this system.

Fourth, one need not use agency adjudication to seek a new rule of law under an unclear statutory standard; rather, one can seek statutory clarification in Congress or a new rule through the informal agency rulemaking process. ${ }^{92}$ These deliberative processes permit the public to enter the debate in a niore fully formed way, are more widely publicized, and by providing a general response rather than one to a specific set of facts, avoid the dangers of singling out. ${ }^{93}$ Granted, some new rules benefit only a small minority of citizens who might lack the political clout to achieve new rules through either legislation or ruleniaking. ${ }^{94}$ But I am not currently addressing the development of constitutional rights, which, because often beneficial to a disenfranchised citizen or group of citizens, might require development through nonpolitical adjudicators. Rather, I am discussing the fleshing out of statutory standards, developed in the first instance by Congress, and developed further by agencies. Both Congress and agencies are political actors, and their statutes and rules create rights and obligations agreed to by a majority of the peoples' representatives.

Fifth, if the foregoing responses do not seem sufficient, we could adopt a system of modified retroactivity, allowing the plaintiff who initially sues to create a new rule to benefit from it, but not permitting other similarly situated plaintiffs to benefit. ${ }^{95}$ This would im-

\footnotetext{
${ }^{90}$ See Fallon and Meltzer, 104 Harv L Rev at 1805 (cited in note 64).

${ }^{91}$ See Harlow v Fitzgerald, 457 US 800 (1982).

${ }^{92}$ See Fuller, Morality of Law at 172-76 (cited in note 7); see also Patel $v$ INS, 638 F2d 1199 (9th Cir 1980) (virtues of making categorical rule through rulemaking procedure).

${ }^{93}$ See Arthur Bonfield, State Administrative Policy Formulation and the Cboice of Lawmaking Metbodology, 42 Admin L Rev 121, 122-36 (1990) (various arguments favoring informal rulemaking over adjudication); Note, $76 \mathrm{Va} \mathrm{L} \mathrm{Rev} \mathrm{at} \mathrm{144-47} \mathrm{(cited} \mathrm{in} \mathrm{note} \mathrm{44)} \mathrm{(same).}$

${ }^{94}$ Cf. Alschuler, 1984 Supreme Court Review at 341 (cited in note 86).

${ }^{95}$ See Stovall v Denno, 388 US 293 (1967); Clark-Cowlitz Joint Operating Agency v FERC, 826 F2d 1074 (DC Cir 1987); Fallon and Meltzer, 104 Harv L Rev at 1806 (cited in note 64).
} 
pose a rule of law cost on the defendant in the initial case, but would grant other similarly situated defendants an immunity from the retroactive application of the new rule. The Court has rejected modified retroactivity in both the criminal and civil contexts, ${ }^{96}$ however, considering the net daniage to the equality norm as greater than the net gain from a systen of nodified retroactivity. It is difficult to quantify the various factors in this "calculation," but given the various ways discussed in this section of aneliorating the concern with deterring litigation that seeks new rules, and given the cost to cardinal values of the rule of law from imposing retroactive obligations, the Court's rejection of modified retroactivity seems an appropriate outcome.

\section{Defending Pure Adjudicative Prospectivity}

When an agency chooses a rule that is not derivable fron sources of law as a Chevron stage 1 nuatter, but rather represents an agency policy choice as a Chevron stage 2 nuatter, then one might conclude that the agency should announce the rule, but apply it to future conduct only. New rules that flesh out unclear statutes could be developed through agency adjudication, but they would be applied prospectively only.

One might object, though, that despite the problenıs with adjudicative retroactivity, pure adjudicative prospectivity is not the solution. On this view, while it is wrong for adjudicators to apply new law retroactively, it is also wrong for then to apply new law merely prospectively. ${ }^{97}$ Adjudicators must renain in the role of interpreter of another's coniniand, and if that command is too vague to yield an answer constrained by congressional intent, but

\footnotetext{
${ }^{7}$ See Griffitb $v$ Kentucky, 479 US 314 (1987) (criminal); James B. Beam Distilling Co. $v$ Georgia, 111 S Ct 2439 (1991) (civil).

${ }^{97}$ See NLRB v Wyman-Gordon Co., 394 US 759, 783 n 2 (1969) (Harlan dissenting) (if "new rule so departs from prior practices that it cannot fairly be applied retroactively," rulemaking is required because agency may not announce purely prospective adjudicative rules). For $\Lambda$ rticle III courts, the Constitution might compel the retroactive application of adjudicative rules. See James B. Beam, $111 \mathrm{~S} \mathrm{Ct}$ at 2449 (Blackmun concurring in the judgment); id at 2450 (Scalia concurring in the judgment); Mackey $v$ United States, 401 US 667, 675 (1971) (I larlan concurring in the judgment); Currier, 51 Va L Rev at 216 (cited in note 18); Fallon and Meltzer, 104 Harv L Rev at 1798 (cited in note 64); but see Note, 71 Yale L J at 929 n 138 (cited in note 9) (quoting from 1 James Moore, Federal Practice 4082-84 (2d ed 1959)). $\Lambda$ gency adjudicators are not govcrned by the strictures of Article III.
} 
rather requires an agency policy choice, then the adjudicators can only point this out and "remand" the matter to the legislature or the rulemaking process. ${ }^{98}$ In this Part, I shall explain that the leading Supreme Court case sometimes thought to reject purely prospective adjudicative rules does not in fact do so. I shall also demonstrate the virtue of such rules.

The leading case on whether agencies may announce a rule through adjudication and apply it purely prospectively is $N L R B v$ Wyman-Gordon Co. ${ }^{99}$ In a prior adjudication, Excelsior Underwear Inc. ${ }^{100}$ the NLRB had considered a union challenge to management's refusing to turn over a list of the names and addresses of employees eligible to vote in a union representation election. Rather than resolving the matter through briefs and arguments from the parties, the NLRB did the following three unusual things: (1) It invited various union and management groups to submit amicus briefs and participate in oral argument. (2) It did not apply the resulting rule-that management must provide a list of eligible employees-to the parties in the adjudication. (3) It declared that the rule would apply only to elections held at least thirty days after the date of the rulimg. In Wyman-Gordon, the NLRB had applied the Excelsior rule in a dispute between the International Brotherhood of Boilermakers and the Wyman-Gordon Co.; the questions before the Court were the validity of the Excelsior rule itself and whether it was otherwise appropriate for the NLRB to order the Company to submit an eligible employees list to the Union.

In an opinion by Justice Fortas, four Justices concluded that the NLRB had improperly promulgated the Excelsior rule. The plurality's principal conceru was that the NLRB had deliberately circumvented the APA rulemaking process. The plurality explained that the NLRB had improperly "purported to establish [a] general rule," and that it had "replace[d] the statutory [rulemaking] scheme with a rulemaking procedure of its own invention." 101 The NLRB had not published the final rule in the Federal Register, and it had solicited arguments from certain groups instead of publishing a general notice of proposed rulemaking in the Federal Reg-

\footnotetext{
${ }^{93}$ Cf. Frank Easterbrook, Statutes' Domains, 50 U Chi L Rev 533 (1983).

99394 US 759 (1969).

100156 NLRB 1236 (1966).

101394 US at $763-64$.
} 
ister. It is in this context - of criticizing the NLRB for using an adjudication to conduct a clandestine rulemaking proceeding-that the plurality noted that the NLRB "did not even apply the rule it made to the parties in the adjudicatory proceeding, the only entities that could properly be subject to the order in that case." ${ }^{102}$ But the concern of the plurality was not that in an otherwise normal adjudication, an agency had decided to apply a rule purely prospectively. Rather, the concern was that "the Board [had] purported to make a rule: i.e., to exercise its quasi-legislative power." 103 Thus, although the Wyman-Gordon plurality disapproved of a particular purely prospective adjudicatory rule, it did so because of the manner in which the NLRB had sought to promulgate that rule; it did not issue a stark holding that purely prospective adjudicative rules are always improper. ${ }^{104}$

The two separate opinions also disapproving the Excelsior rule more clearly rejected the very concept of a purely prospective adjudicative rule. ${ }^{105}$ But the reasoning of these opinions is open to challenge. Justice Harlan concluded, "The language of the [APA] does not support the Government's claim that an agency is 'adjudicating' when it announces a rule which it refuses to apply in the dispute before it." ${ }^{106} \mathrm{He}$ reached this result in the following manner: An agency "adjudicates" 107 only when it formulates an "order," which is defined as what an agency issues in "a matter other than rulemak-

\footnotetext{
${ }^{102}$ Id at 765.

${ }^{103}$ Id; see Cornelius Peck, A Critiqute of the National Labor Relations Board's Performance in Policy Formulation: Adjudication and Rule-Making, 117 U Pa L Rev 254, 266 (1968) (in Excelsior, .NLRB engaged in "the fiction of adjudication").

${ }^{104}$ Although the plurality rejected the Excelsior rule, and although the NLRB had cited Excelsior in ordering the Wyman-Gordon Co. to furnish an eligible employee list, the plurality nonetheless upheld the order that the Wyman-Gordon Co. furnish such a list! In apparent disregard of the Cbenery I tenet that agency action must be justified on the basis the agency cites, the plurality explained that "[t]o remand would be an idle and useless formality" because the NLRB clearly has the substantive power to order such a list. 394 US at $766 \mathrm{n}$ 6. Even though the other two Justices who disapproved of the Excelsior rnle would have followed Cbenery $I$ and reversed the NLRB in this case, see id at 775 (Douglas dissenting); id at 780 (Harlan dissenting), the plurality was joined in the result by the other three Justices, who thought the Excelsior rule legitimate (but who also indicated they would have remanded pursuant to Cbenery $I$ if they had disapproved of the Excelsior rule). See id at 769 (Black concurring in the result).

${ }^{105}$ Id at 775 (Douglas dissenting); id at 780 (Harlan dissenting).

$106 \mathrm{ld}$ at 780 .

${ }^{107} 5$ USC $\S 551(7)$.
} 
ing." 108 A rule made through rulemaking procedures has "future effect" only. ${ }^{109}$ Therefore, because the NLRB declared that the Excelsior rule would be effective only in the future, that rule had to be issued through a rulemaking proceeding.

This argument is flawed. There is indeed a good argument that the APA requires rulemaking rules to have future effect only. ${ }^{110}$ But it does not follow, from either policy or the statutory text, that àn adjudicative rule may not, on occasion, also have future effect only. I shall discuss the policy concerus below. As a textual matter, the APA does not require that an adjudicative rule have at least retroactive effect. ${ }^{11}$ The APA does not say, as Justice Harlan's logic implies, that all rules having future effect only must be announced through rulemaking proceedings. Requiring the rules that are announced through rulemaking proceedings to have future effect only is not the same thing as forbidding adjudicative rules from having such effect. The APA does the former; it does not do the latter. ${ }^{112}$

Justice Douglas agreed with Justice Harlan that "an agency is not adjudicating when it is making a rule to fit future cases." 113 As Justice Douglas explained, informal rulemaking ensures at least two values that adjudication might thwart. First, by requiring a notice of proposed rulemaking to which any member of the public may respond, the rulemaking procedures ensure a generality of participation that might be lacking in the often bipolar world of adjudication. Second, by publishing the notice of proposed rulemaking and the final rule in a commonly available general source -the Federal Register-rulemaking ensures an openness of debate that might be lost in the less public world of adjudication.

To be sure, these arguments somewhat overstate the differences between rulemaking and adjudication. In important adjudications, members of the affected communities can often enter as intervenors or submit annicus briefs to ensure a wider degree of participation

\footnotetext{
${ }^{108}$ Id at $\$ 551(6)$.

${ }^{109}$ Id at $\$ \S 551(4)(5)$.

${ }^{110}$ See note 27 and accompanying text.

III See 5 USC $\S \$ 51(6)(7)$.

112 Even if Justice Harlan's position were correct, one need not concede the demise of pure adjudicative prospectivity; rather, if persuaded that pure adjudicative prospectivity is a valuable agency tool, Congress could amend the APA to permit it.

113394 US at 777.
} 
in the construction of rules. Also, the availability of adjudicative agency decisions through looseleaf services or computer databases mitigates the "hidden" nature of adjudicative rules. But the rulemaking procedures still offer the best mechanism for constructing general rules that respond to, and are available to, the community at large.

Nonetheless, there are good reasons to support the occasional agency announcement of an adjudicative rule applied merely prospectively. First, if an adjudicator has made a policy determination regarding how to flesh out an unclear statutory standard and thus has concluded that rule of law concerns militate against retroactive application, the adjudicator can serve the purposes of both law reform and the rule of law by announcing the rule but applying it merely prospectively. ${ }^{114} \mathrm{We}$ can forbid agencies from doing what the NLRB did in Wyman-Gordon-deliberately use an adjudication, from the outset, to conduct a quasi-rulemaking proceeding-but still endorse a purely prospective adjudicative rule that results from a standard adjudication. ${ }^{115}$ Second, in many cases, the parties to the litigation will be affected by the ruling's prospective effects, even if the new rule is not applied to their antecedent conduct. Thus, the ruling will not be purely advisory, and the possibility that the adjudicator will not apply the rule of the case to antecedent conduct will deter only a small amount of litigation. ${ }^{116}$

Third, if an agency may not apply a rule purely prospectively but must also be alert to improper retroactive application, there will be times that an adjudicator will have to dismiss an adjudication after time and energy have been spent on it, because the rule the adjudicator chose could neither be properly applied to the parties nor announced purely prospectively. ${ }^{117}$ Fourth, a strict rule against pure adjudicative prospectivity, combined with a healthy regard for the problems of retroactive application of new adjudicative rules, would perhaps force too many issues out of adjudication

\footnotetext{
${ }^{114}$ See id at 773-74 (Black concurring in the result).

${ }^{115}$ As Justice Black pointed out in his Wyman-Gordon opinion, even in Excelsior, "The Board did not abstractly decide out of the blue to announce a brand new rule of law to govern labor activities in the future, but rather established the procedure as a direct consequence of the proper exercise of its adjudicatory powers." Id at 773 (Black concurring in the result); see also Mishkin, 79 Harv L Rev at 61 (cited in note 57).

116 See Part IVD.

${ }^{117}$ See 394 US at 774-75 (Black dissenting).
} 
and onto the rulemaking docket. Although rulemaking should be the primary source for the creation of agency policy out of unclear statutes, permitting pure adjudicative prospectivity would ensure agency attention even to those smaller issues that might not make it to the rulemaking docket. Fifth, agencies might sometimes develop better rules by responding to the concrete specifics of adjudicative situations than by considering the more abstract comments submitted during the notice-and-comment rulemaking process. In sum, the advantages of the occasional announcement of a purely prospective adjudicative rule outweigh the disadvantages. ${ }^{118}$

Against these arguments favoring pure adjudicative prospectivity, Wyman-Gordon seems a weak precedential barrier. Although one might construe that case as "holding" that agencies lack the power to announce a purely prospective new rule through adjudication, ${ }^{119}$ there are reasons to believe the Court would not prevent an agency from doing so in an appropriate case. The Court has long adhered to the fundamental proposition that an agency generally has discretion to choose either rulemaking or adjudication to announce new rules. ${ }^{120}$ Although approving significant adjudicative

${ }^{118}$ In apparent, although often silent, recognition of these arguments, the Court has, in the judicial context, adopted pure adjudicative prospectivity both for new law that overruled old law, see Buckley v Valeo, 424 US I (1976); Cbevron Oil Co. v Huson, 404 US 97 (1971); Mackey v United States, 401 US 667 (1971); Desist v United States, 394 US 244 (1969); Stovall v Denno, 388 US 293 (1967); Jobnson v New Jersey, 384 US 719 (1966); Linkletter v Walker, 381 US 618 (1965); Reynolds v Sims, 377 US 533 (1964); James v United States, 366 US 213 (1961), and for new law that merely fleshed out vague mandates, see Allen $v$ State $B d$. of Elections, 393 US 544 (1969); England v Louisiana State Bd. of Medical Examiners, 375 US 411 (1964); see also Cheornon Oil Co. v Huson, 404 US 97, 106 (1971); Halliday v United States, 394 US 831, 833 (1969) (Harlan concurring in the judgment). The Court has also held that a party to state-court litigation does not have a federal constitutional right to retroactive application of the rule announced in the adjudication. Great N.R. Co. v Sunburst Oil \& Refining Co., 287 US 358 (1932).

${ }^{119}$ See Bowen v Georgetown Univ. Hosp., 109 S Ct 468, 478 (1988) (Scalia concurring); Merton Bernstein, Tbe NLRB's Adjudication-Rule Making Dilemma Under tbe Administrative Procedure Act, 4 Yale L J 571, 610 (1970).

${ }^{120}$ See NLRB v Bell Aerospace Co., 416 US 267 (1974); SEC v Cbenery Corp., 332 US 194 (1947). Lower courts have usually followed suit. Sec note 44. For two departures, see First Bancorp. v Board of Governors, 728 F2d 434 (10th Cir 1984) (invalidating a new rule, although applied to the parties, because agency should promulgate new, broad rule through rulemaking procedure); Ford Motor Co. v FTC, 673 F2d 1008, 1010 (9th Cir 1981) (setring aside adjudicative order, "because the rule of the case ... will have general application"), cert denied, 459 US 999 (1982).

The Court has, though, encouraged agencies to use the rulemaking process when they know in advance that they want to announce new categorical rules. See Morton $v$ Ruiz, 415 US 199 (1974); SEC v Cbenery Corp., 332 US 194, 202 (1947); see also Davis, Discretionary Justice at 61-64 (cited in note 51) (suggesting the promulgation of rules phrased as responses to factual hypotheticals). 
retroactivity, the Court has left the door open (without significant discussion) for denial of such retroactivity if the equities warrant. ${ }^{121}$ The Court has not indicated or implied that in such a case, an agency would be deprived of its usual discretion to choose adjudication over rulemaking. Thus, if an agency may choose adjudication, and if the equities warrant a denial of retroactivity, then the agency would be permitted to announce a new rule through adjudication prospectively only. ${ }^{122}$

In addition, a flat rule against pure adjudicative prospectivity in the agency context is somewhat inconsistent with the Court's applying its own decisions prospectively; ${ }^{123}$ Wyman-Gordon does not address this line of cases. ${ }^{124}$ Finally, some lower courts have, in the face of Wyman-Gordon, approved purely prospective adjudicative rulemaking, ${ }^{125}$ and the Court might find the views of its appellate colleagues persuasive. Indeed, as discussed above, four of the six Wyman-Gordon Justices who voted against pure adjudicative prospectivity in that case seemed more concerned with the NLRB's quasi-notice and comment rulemaking procedure and less concerned with the prospectivity of the rule simpliciter. ${ }^{126}$

\section{Conclusion}

Although the Court has recently attempted to shape the contours of adjudicative retroactivity in the setting of both criminal ${ }^{127}$ and civil ${ }^{128}$ constitutional law, its attention has not turned to

\footnotetext{
${ }^{121}$ See NLRB v Bell Aerospace Co., 416 US 267, 294 (1974); SEC v Chenery Corp., 332 US 194, 203 (1947).

${ }^{122}$ See NLRB $v$ Wyman-Gordon Co., 394 US 759, 772 (1969) (Black concurring in the result); Stephen Breyer and Richard Stewart, Administrative Law and Regulatory Policy $484 \mathrm{n}$ 76 (2d ed 1985); Robinson, 4 U Pa L Rev at 510 (cited in note 28).

${ }^{123}$ See Robinson, 4 U Pa L Rev at 512-13 (cited in note 28); see note 118.

${ }^{124}$ See McDonald $v$ Watt, 653 F2d 1035, $1042 \mathrm{n} 17$ (5th Cir 1981).

${ }^{125}$ See Petrolite Corp. v FERC, 667 F2d 664 (8th Cir 1981); McDonald $v$ Watt, 653 F2d 1035 (5th Cir 1981); Transwestern Pipeline Co. v FERC, 626 F2d 1266 (5th Cir 1980), cert denied, 451 US 937 (1981); see also H. \& F. Bineb Co. $v$ NLRB, 456 F2d 357, 365 (2d Cir 1972) (Friendly) ("It is indeed surprising that the Board should so consistently have refused ... to develop techniques of prospective ruling and overruling save in one notable instance where it overdid this. NLRB $v$ Wyman-Gordon"); Shapiro, 78 Harv L Rev at 934 (cited in note 28).

${ }^{126}$ See McDonald $v$ Watt, 653 F2d 1035, 1042 n 17 (5th Cir 1981).

${ }^{127}$ See Teague $v$ Lane, 109 S Ct 1060 (1989); Griffitb v Kentucky, 479 US 314 (1987). The Court has also held that its decisions should not be applied to a state defendant's federal
} 
the related issue of adjudicative retroactivity in administrative law. Even as it has provided a clearer picture of the lawmaking powers of administrative agencies-powers that are exercised through both rulemaking and adjudication-the Court has not revisited its forty-five-year-old doctrine permitting broad administrative adjudicative retroactivity. But Cheoron's insight into agency lawnraking deniands a new look at Chenery II's understanding of agency adjudication. Chevron's two-stage test for determining when courts nust permit agencies to make law can serve as the model for determining when agencies should be disabled fron applying their rules retroactively. For Chevron can help us see the connection between interpretive constraints and notice of what the law is. When there is insufficient evidence of congressional intent to bind an agency to a particular regulatory choice, then there is insufficient evidence of congressional intent for the affected citizens to know what the law is, and to conform their behavior accordingly. When a regulatory choice is properly deeined an act of lawniaking, then to the extent that we do not permit laws to apply retroactively, the regulatory choice should also not apply retroactively, whether announced in a rulemaking or in an adjudication.

habeas corpus proceeding unless the decisions were "dictated by precedent existing at the time the petitioner's conviction became final." Butler v McKellar, $110 \mathrm{~S} \mathrm{Ct} 1212,1214$ (1990). A decision is "dictated by precedent" only if there are no "reasonable, good-faith interpretations" to the contrary. Id at 1217. Although Butler erects a steep barrier to adjudicative retroactivity in the habeas corpus setting, and the Cbevron model also enunciates a stricter rule against adjudicative retroactivity than has been previously applied in the administrative law context, one test should not be confused with the other. There are at least two important distinctions. First, Butler's concern is with the law that existed on the date the defendant's conviction became final. After Butler, in the habeas setting a court need not pay attention to which rule existed at the time of the primary conduct at issue (usually that of the defendant or the police). Butler's concern is not with notice and the rule of law; rather, Butler focuses on federalism, and whether the state courts made "reasonable, good-faith interpretations of existing precedents." Id. Second, the Butler test permitting retroactivity only when a new rule is "dictated by precedent" is more stringent than my test permitting retroactivity when one can ascertain congressional intent on a question of statutory interpretation. The difference between the tests is based at least in part on the difference between the purposes behind the tests, bolstering federalism in Butler, adhering to rule of law values, in the Cbevron model.

${ }^{128}$ See James B. Beam Distilling Co. v Georgia, 111 S Cr 2439 (1991); American Trucking Assts., Inc. v Sinith, 110 S Ct 2323 (1990). 
